\title{
Kaum As Social Capital Environment in Empowering Minangkabau Communities
}

\author{
Muhamad Jamil' ${ }^{1}$, M Bahri Ghazali², Hasan Mukmin², Syafrimen Syafril, Welhendri Azwar ${ }^{3}$, Azhar \\ Jaafar $^{4}$
}

${ }^{1}$ Islamic High School of Religion Tarbiyah Islamiyah Foundation's in Padang. Islamic Community Development Doctoral Program Student UIN Raden Intan Lampung, ${ }^{2}$ Islamic University Raden Intan Lampung, Bandar Lampung, Indonesia, ${ }^{3}$ State Islamic University (UIN) Imam Bonjol Padang, West Sumatera, Indonesia, ${ }^{4}$ University College of Yayasan Pahang Malaysia.

\begin{tabular}{|c|c|}
\hline ARTICLE INFO & ABSTRACT \\
\hline Article history: & \multirow{12}{*}{$\begin{array}{l}\text { Empowerment is the process of creating community independence } \\
\text { through the management of various capital, especially social capital } \\
\text { in the community itself (self-help). Some research shows that } \\
\text { development in Minangkabau is considered successful in the physical } \\
\text { field. However, behind the success of physical development has an } \\
\text { impact on erosion of socio-cultural that inherent on the Minangkabau } \\
\text { community. This article analyzes the various forms of social capital } \\
\text { found in Kaum as the local community of the Minangkabau people in } \\
\text { the perspective of social capital, trust, norms, and network. The } \\
\text { multicase study is used in the epistemological proof step by involving } \\
\text { five (5) Kaum as the locus of study. The findings in this study } \\
\text { conclude that; First, in the perspective of trust people have a high } \\
\text { level of awareness so that the power to be with one another and help } \\
\text { become more dominant. Secondly, customary and Islamic norms are } \\
\text { deeply institutionalized in the Kaum so that social control and safety } \\
\text { networks are more effective. The three, networks in the Kaum are } \\
\text { permanent as the basis for laying out various interests of } \\
\text { empowerment. }\end{array}$} \\
\hline Received: July 3, 2021 & \\
\hline Revised: July 5, 2021 & \\
\hline Accepted: August 10, 2021 & \\
\hline Keywords: & \\
\hline Kaum. & \\
\hline Social Capital, & \\
\hline $\begin{array}{l}\text { Minangkabau, } \\
\text { Communities }\end{array}$ & \\
\hline & \\
\hline Clonflict of Interest: & \\
\hline None & \\
\hline & \\
\hline
\end{tabular}

None

Corresponding Author: Muhamad Jamil, Islamic High School of Religion Tarbiyah Islamiyah Foundation's in Padang. Islamic Community Development Doctoral Program Student UIN Raden Intan Lampung, Email: jamiljaey@gmail.com

(C) Muhamad Jamil, M Bahri Ghazali, Hasan Mukmin, Syafrimen Syafril, Welhendri Azwar, Azhar Jaafar

This is an open access article under the CC BY-SA 4.0 international license.

\section{Introduction}

Minang people who group organisms based on matrilineal are called Kaum, reinforced by adat structures, communal-individual ownership systems [1]. Minang people are also known as people who uphold traditional and Islamic values. Even Hamka said that the requirement to become a Minangkabau community was to make Islam the basis of its beliefs [2]. However, this situation has changed a lot along with the course of development and globalization [3]. "State capitalisme" or the nationalization of global culture in the locality of the community specifically the Minangkabau, generally seen in two models of change of Kaum [4]. First, there is a stretch of interpersonal relations in the Kaum which was previously very thick in the Minangkabau community. Ownership is dominated by the system of personal ownership, status and role in the structure of the people become ambiguous. Interpersonal emotional relationships in the matrilineal system become rational-individualistic relationships [5]. Cultural homogeneity began to transform into cultural heterogeneity, as well as customary behavior and traditions transformed into formality, Freed W. Rigg's called it "the prismatic society" [6]. Second, the people who still survive with the locality tradition. Characterized by a warm relationship on interpersonal aspects in the Kaum, the ownership system is balanced or dominated between communality and individuality, status and role are well maintained [7]. Traditional people have immunity in the form of energy to live in the midst of globalization of national development. 
This energy is able to control the pattern of individual behavior for life called social capital. The value system, social network, and trust owned by the People, and with it the People become "controlled" by the values for meeting the needs. The ability to help himself (self-help) in managing various assets such as; social capital, symbolic capital, cultural capital and so on. States that this is the true nature of community empowerment [8]. Studies on community empowerment have developed in various scientific disciplines and make it a scientific approach. Likewise, studies relating to social capital. However, not many studies have touched the People as an object of study. For this reason, this article tries to answer the question of how to Kaum as social capital empowering minangkabau communities?

\section{Materials and methods}

\subsection{Social Capital and Local Communities}

Social capital is a group of people which has the potential to be caused by the process of social interaction, by doing so facilitating inter-group actions in the structure of society both horizontal and vertical to ensure the availability of various information, norms, networks, reciprocity, and also cooperation, so that it can be used in specific purposes and objectives in various fields [9]. This explanation can be understood that the existence of social capital is in the community network that is directed to work together to achieve common goals [10]. Referring to the concept of social capital above, there are many elements to build social capital, including; trusts, norms, networks, information, reciprocity, and cooperation. In this article only discusses three main buildings which are widely discussed by social capital experts, namely; trusts, norms, networks. As Fukuyama explains, honest, orderly behavior, and cooperation, are congressional forms of trust in a society [11]. Norms that are shared in a society grow together with the expectations of the community. Social trust is the application of this understanding. Cox then notes that social rules tend to be positive and relationships are also cooperative in societies that have a high level of trust [12]. The explanation above can be concluded that social capital can be observed through social connections, honor and self-esteem owned by community members. The point is to build honesty in the social environment [13]. The description above espectáculos the concrete form of trust is; honesty, mutual cooperation, attitude of responsibility, self-respect, and honor. The next building is a norm consisting of understandings, values, hopes and goals that are believed and carried out together by a group of people. Religion, moral guidance, secular standards, professional codes of ethics are the source of Norms. The atmosphere of cooperation in a community is built and developed based on past history, which is then used to work together. Pre-conditions and other social products are manifestations of the intended social norms. Apart from this, the value structure builds the ability to use cultural symbols as distinguishing marks that mark them in social structures [14]. Next up is social networks. Social networks in cooperation between people are a manifestation of the social capital infrastructure. The space for communication and interaction becomes a facilitator of social networks so that the strength of cooperation and trust are combined. A society will be strong when it has a strong social network, on the contrary, the community becomes weak when the social network is also weak. When individuals meet with other individuals, then it is realized or not thick interaction that will be developed formally, or informally. Putnam added that when a social network of a society is strong, then automatically the feeling of cooperation and participation of the network will be beneficial for the achievement of shared goals [15]. Basically, networks take the form of interactions that encourage mutually beneficial mutual cooperation, have long lasting network values, which form solidarity thereby increasing material profit or symbolic duration [16]. Thus, it can be understood that social networks are relationships that occur between individuals or individuals with groups, or groups with community groups caused by the process of birth, marriage, friendship, or other causes so that the potential for cooperation and building solidarity in various interests, formal or informal.

There are several indicators of the above explanation relating to the size of the social sector that is completely absent, by finding keywords from the form that becomes the foundation of a social capital. Elements to measure social capital include; (i) Feelings of identity; (ii) feelings of belonging or vice versa, feelings of alienation; (iii) belief systems and ideology; (iv) Values and goals; (v) Fears; (vi) Attitudes towards other members in the community; (vii) Perceptions regarding access to services, resources and facilities (eg employment, income, education, housing, health, transportation, social security); (viii) Opinions on government performance that have been carried out previously; (ix) Confidence in community institutions and people in general; (x) Level of trust; (Satisfaction in life and other fields of society; (xi) Expectations to be achieved in the future [17], [18]. The above explanation concludes that social capital grows from the bottom (bottom-up), is not hierarchical and is attached to mutually beneficial interactions. This makes it clear that social capital is not a product or initiative, and is not a policy of any government, but rather grows from and exists in the community itself. Identical communities that have social capital are local communities. Ferdinand Tonies prefers the word "Gemeinschaft" to describe the local community, which has characteristics; intimate, intimate, sympathetic, interdependent, and reflecting social awareness together. different from "Gesellschaft" or casual relationships, temporary, without emotional investment, and based on 
personal interests [19], [20], [21]. Based on the local community indicators given by Tonies above, it can be concluded that the local community in Minangkabau is Kaum.

\subsection{Place and time of research}

In this study, the authors agree with Yin [22]. This research is part of the case study that was observed and then concluded that the case relating to the focus of the problem lies in Nagari Tabek Patah Salimpaung Subdistrict, Tanah Datar District. The area of Nagari Tabek Patah is 920 Ha. The number of Nagari Tabek Patah residents in the 2010 population census was 3240 people as of June 2010. Nagari Tabek Patah consists of four Jorong, namely, (1) Jorong Tabek Patah, (2) Jorong Datar, (3) Jorong Koto, and (4) Jorong Koto Alam. From these four jorong, scattered Kaums that inhabit the jorong. Among these Kaums are;

Table 1. Data of Kaum in Nagari Tabek Patah

\begin{tabular}{|c|c|c|c|c|}
\hline $\mathbf{0}$ & Suku Names & $\begin{array}{c}\text { umber of } \\
\text { Kaum }\end{array}$ & $\begin{array}{c}\text { mber of }_{\text {Headers }}^{\mathrm{Nu}} \\
\text { rson) }\end{array}$ & Join in the $S u k u$ \\
\hline & 2 & & 4 & 5 \\
\hline & Caniago & & 5 & Caniago \\
\hline & Bodi & 2 & 12 & Caniago \\
\hline & Cingkuang & 6 & 16 & Caniago \\
\hline & Dalimo & & 6 & Dalimo \\
\hline & Payo Bada & & 5 & Dalimo \\
\hline & Tanjung & & 4 & Dalimo \\
\hline & Melayu & & 4 & Mandahiling \\
\hline & Sikumbang & & 4 & Mandahiling \\
\hline & Mandahiling & & 3 & Mandahiling \\
\hline 0 & Pilliang Laweh & & 8 & Piliang \\
\hline 1 & Pilliang Sani & 1 & 11 & Piliang \\
\hline 2 & Parik Cancang & 4 & 14 & Piliang \\
\hline 3 & Kuti Anyie & & 2 & Kuti Anyie \\
\hline 4 & Patapang & & 3 & Kuti Anyie \\
\hline 5 & Salo & & 5 & Kuti Anyie \\
\hline 6 & Jambak & & 5 & Kuti Anyie \\
\hline & Amount & 07 & 10 & 5 Persukuan \\
\hline
\end{tabular}

\subsection{Data types and sources}

This research requires two types of data, namely; primary data and secondary data. The Sage Encyclopedia of Qualitative Research Methods gives the term data to refer to a collection of information. A more detailed definition includes the type of data that is combined into information collected such as numbers, words, images, videos, audio, and concepts. Many data definitions include word facts, or facts, but this implies a conclusion about the data and not the data itself [23]. However, they have created special instruments and 
techniques to observe and measure these aspects indirectly. The primary data in this study are the activities of Kaum members in daily life in the context of empowerment based on local wisdom or social capital, as well as data obtained from traditional leaders in the Kaum who have knowledge especially about norm systems that control between individuals in life. This data is very necessary because not everything that is done by individuals in the Kaum understands the values that affect them in their activities. Secondary data is interpreted as data that was not obtained from the first source. The data in this scope the author collected from sources outside the Kaum itself, such as; formal leadership in the nagari, namely; Wali Nagari, Wali Jorong, and traditional leaders, outside the Kaum. The next data is documentation in the form of; literature in relation to the focus of the problem in research, also includes demographic documentation and profiles on the Nagari Tabek Patah. The main data sources in a qualitative study are; words and actions, while documents, such as; video, audio, and literature are additional data . Based on this opinion, in this study the main data sources are the words and actions of the members of the Kaum in terms of social capital. This main data source is recorded through written records or through a recorder. This is in line with Kohar that in qualitative research, the main instrument of research is the researcher itself [24]. This is because data collection is more self-reliant through participant observation as a basis for data collection power. Sampling in case study research generally uses purposive sampling, which is to focus on informants who are rich in information for deeper study. The intention is that information-rich are cases where researchers can learn a lot about various issues that are very important in order to achieve goals and interpret the phenomenon of research being investigated. Thus the case study approach offers flexibility in selecting samples, the number of cases investigated, and flexibility with regard to sampling techniques. Considerations in this study for taking a research sample; first, the number of people who are the object of research are people who still have conditions that are at least still complete based on traditional indicators. Second, those who have been grouped into complete and incomplete groups will be chosen by those who complete the requirements according to the trational measures. Third, the sample aims to obtain only 5 (five) people who are included in the traditionally complete criteria. The groups are at once the locos of study, namely;
a. Dt. Simarajo Lelo, Kutianyir Suku.
b. Dt. Badangiang, Tanjung Suku
c. Dt. Tan Pahlawan, the Piliang Sani Suku
d. Dt. Mantiko Bali Nan Putih, Parik Cancang Suku
e. Dt. Sinaro Nan Batembang, Dalimo Suku

\subsection{Data analisys}

Observation, interview and document analysis are data collection techniques in this study[25]. A series of systematic activities were carried out to analyze the data in this study, phenomena, data categories, concepts/ definitions, propositions, and generalizations [26]. This qualitative data is analyzed together with the interpretation of data together with the theory.

\section{Results and discussion}

Poverty, racism, oppression are "biological children" of helplessness, so it takes power to power. The best known and instrumental use of power is the ability to control people or objects. Rowlands calls this power "power over" and describes it as "zero-sum" or "limited supply" of power: the more power one has, the less one has [27]. So, the process of providing power and power to the community is called community empowerment.

To that end, empowerment aims in two directions, namely (a) free from the shackles of poverty and underdevelopment, and (b) the position of the social strata in a strong power structure. Both must be taken as targets of empowerment efforts [28]. This reason is due to an empowerment process in essence striving for people to gain power and power in order to free themselves in making decisions and determining their own actions, without intervention from any party. The people are a group of people who live together, have social organizations, natural resources, and values. In quantity, the Kaum consists of a collection of several families (nuclear family) grouped by maternal lineage. Based on the above understanding, the existence of the Kaum is a group called the local community. According to several views Hamka, Edison and Nasrun, Radjab indicators of a Kaum can be seen from table B.1 below [29], [30], [31]; 
Table 2. Indicators of Kaum

\begin{tabular}{|c|c|c|}
\hline No. & Indicator & Description \\
\hline 1 & Group based on maternal lineages & Kinship system is built based on women. \\
\hline 2 & Have the same social awareness & $\begin{array}{l}\text { Understanding each other in the form of mutual respect } \\
\text { between members of the Kaum and being aware of each } \\
\text { other's social status. }\end{array}$ \\
\hline 3 & $\begin{array}{l}\text { Has a heritage in the form of; land / } \\
\text { rice fields / forest / lake }\end{array}$ & $\begin{array}{l}\text { The Kaum at least have a inheritance called a high } \\
\text { treasure. }\end{array}$ \\
\hline 4 & Relationships that occur are emotional & This is due to the extended family. \\
\hline 5 & Dependent & Members' needs tend to be communally met. \\
\hline 3 & $\begin{array}{l}\text { Having a social structure based on adat } \\
\text { and religion }\end{array}$ & $\begin{array}{l}\text { The existing social structure is built from religious and } \\
\text { customary values. }\end{array}$ \\
\hline 4 & Having legal territory & $\begin{array}{l}\text { The jurisdiction of a Kaum is recognized by the Kaum } \\
\text { outside the Kaum. }\end{array}$ \\
\hline 5 & $\begin{array}{l}\text { Bath edge, cemetery pandam, gadang } \\
\text { house, rangkiang (economic system). }\end{array}$ & $\begin{array}{l}\text { The completeness referred to must be absolutely owned by } \\
\text { the Kaum. }\end{array}$ \\
\hline 6 & sako or traditional title & called sako. \\
\hline
\end{tabular}

Noting the above indicators, it can be understood that the Kaum as a local community in Minangkabau have social capital. Furthermore, following Pierre Bourdieu's opinion in The Sociology of Economic Life, The Kaum also have; economic capital, symbolic capital, and cultural capital [32]. Social capital for community empowerment is as follows; First the trust of the Kaum. It can be seen from the indicators of a Kaum as table B.1 above, that the kinship system built in one clan or extended family (clan) will have a high mutual awareness of the status and role that is being "played" by individuals in life [33]. Trust will not grow if there is a dysfunction of status and role in a community / community [34]. Both customary and Islamic norms are deeply institutionalized in Kaum. The people hold four types of adat; (i) Adopted adat is a rule made by adat holders that applies to the local environment through a process of deliberation, (ii) adat term adat / adat, which is the norm in a village that follows the course of community development or the dynamics of community life, (iii) Adhered customs / customary traditions, are the habits of a person in community life that may be added or subtracted and may even be abandoned, as long as it does not violate the Minang foundation of thinking, namely Alur-Patut, Rasa-Check, and Deliberation-Consensus, (iv) adat which is actually customary, namely the basic rules or philosophies that underlie Minang tribal life that apply from generation to generation without being determined by the time, place and circumstances in accordance with the philosophy of "indak lakang dek paneh, indak lapuak dek hujan (will not dry by heat, will not be weathered by rain". Values: shyness or self-esteem, empathy, honesty, trustworthiness, and altruism, hard work, crafts, thrift, infatuation, innovation, respect for achievement, vision for the future, and rational in the Kaum built from the four customs [35]. All three networks in the Kaum are permanent. This term is influenced by customary values which say that "how many people cannot be dumped, how come they can not be used" in other words, the character and behavior of members who violate the rules will not be able to change the condition that an individual is a member of the People from which he originated, except when it has violated the actual customary adat namely, out of Islam. The permanent network within the People allows effective communication and strengthens cooperation to meet the needs of the individual's life and social needs within the People. The three buildings of social capital are likened to tigo tali sa pilin which mutually reinforce one another, which is owned by the People in Minangkabau [36]. For this reason, the purpose of community empowerment in the field of; economic, religious, educational, political, environmental, and social can be achieved while preserving various potentials that are owned by the community [37]. Seeing the importance of social capital and the People in Minangkabau, the strength and potential should be empowered for the realization of social justice not only in the Minangkabau community, but for all humanity.

\section{Conclusion}

Community Empowerment aims to; (i) releasing the shackles of poverty and underdevelopment, and (ii) strengthening the position of the layers of society in the power structure. Empowerment that has been running so far has not yet reached the goal, even eroding the existing socio-cultural order. Community empowerment should be able to preserve the value of local wisdom. In Minangkabau, the possibility is also owned by all people in the world, having a variety of capital that is potentially empowered for community empowerment, especially social capital. To that end, studies and empowerment programs should make social 
capital and the people as objects of empowerment, in accordance with the philosophy of life that applies to each community. In Minangkabau, the appropriate philosophy of empowerment is "mambaliakkan pinang $k a$ tampuaknyo, siriah ka gagangnyo (return the betel nut to its reel, betel to the handle)" with other words empowering the community with and the values that apply in the community itself.

\section{References}

[1] Syahrizal \& Meiyenti S 2012. Sistem Kekerabatan Minangkabau Kontemporer: Suatu Kajian Perubahan dan Keberlangsungan Sistem Kekerabatan Matrilineal Minangkabau. In The 4th International Conference of Indonesian Studies: Unity. Diversity, and Future.

[2] Hamka 1984 Islam dan Adat Minangkabau

[3] Insya Musa M 2015 Dampak Pengaruh Globalisasi Bagi Kehidupan Bangsa Indonesia. Pendidikan Guru Sekolah Dasar (PGSD) JURNAL PESONA DASAR Universitas Syiah Kuala.

[4] Hertz N 2001 The silent takeover: global capitalism and the death of democracy. (London: Heinemann).

[5] Manaf A A 2009 Masalah dan cabaran tanah adat Minang di dunia Melayu Malaysia dan Indonesia. Geografia - Malaysian Journal of Society and Space.

[6] Riggs Fred W 1965 Prismatic Society and Financial Administration (Cornell University SAGE Publishing).

[7] Soekanto Soejono 2002. Sosiologi Suatu Pengantar (Jakarta: PT RajaGrafindo).

[8] Azwar W 2014 Sosiologi Dakwah (Padang: Imam Bonjol Press).

[9] Coleman J 2000 Social Capital in the Creation of Human Capital. In Knowledge and Social Capital.

[10] Affandi Roseno et al 2020 Implementing SDG to Village Level by Integrating Social Capital Theory and Value Chain: (Case of Village Tourism Pentingsari in Yogyakarta, Indonesia) Journal of ASEAN Studies.

[11] Fukuyama F 1992 The End of History and The Last Man (New York: Free Press).

[12] Cox Eva 1995 A Truly Civil Society (Sydney: ABC Book).

[13] Field John 2016 Modal Sosial, (Bantul: Kreasi Wacana Offset).

[14] Swanson Eric et al 2020 The effect of leader competencies on knowledge sharing and job performance: Social capital theory Journal of Hospitality and Tourism Management journal homepage.

[15] Putnam Robert D 2004 A decline of social capital? The german case.

[16] Field John 2016 Modal Sosial (Bantul: Kreasi Wacana Offset).

[17] Ievdokymov Viktor et al 2020 Social capital measurement based on "The value explorer" method, Management Science Letters 10 1161-1168.

[18] Suharto Edi Membangun masyarakat memberdayakan rakyat; kajian strategis pembangunan kesejahteraan sosial dan pekerjaan sosial, Bandung: Refika Aditama.

[19] Krämer Benjamin 2020, Gesellschaft als gemeinschaft? Akademischer und politischer populismus. In V. Gehrau, A. Waldherr, \& A. Scholl (Hrsg.), Integration durch Kommunikation: Jahrbuch der Publizistikund Kommunikationswissenschaft S. 69-79). Münster: Deutsche Gesellschaft für Publizistikund Kommunikationswissenschaft e.V.

[20] Borgatta Edgar F and Rhonda JV Montgomery 2000 Encyclopedia of sociology (New York, Macmillan References Data).

[21] Azwar W 2018 The resistance of local wisdom towards radicalism: the study of the tarekat community of West Sumatra Indonesia, $S$ H $\mathbf{2 6}$ 75-102

[22] Yin Robert K 2018 Case study research and applications (United Kingdom: SAGE Publications, Inc.

[23] Neuman W Lawrence 2014, Sosial research methods; qualitative and quantitative approaches (Pearson Education Limited).

[24] Kohar Wakidul et al 2012 Kompetensi komunikasi ulama lintas budaya: studi kasus pelestarian nilai adat budaya, dan agama di nagari lunang silaut Puslit IAIN IB Padang.

[25] Ary Donald et al 2006 Introduction to research in education (USA: Wadsworth Cengage)

[26] Wallace Walter L 1990 Metode logka ilmu sosial (Jakarta: Bumi Aksara).

[27] Svendson, Gert Tinggaard, dan Gunnar Lind Haase Svendsen 2009 Handbook of social capital: the 
troika of sociology, political science and economics.

[28] Napu Yakop et al 2009 Pengembangan masyarakat: manusia satu sama lain saling mendidik dengan perantara dunia (Gorontalo: PNF Press).

[29] Hamka 1984 Islam dan adat minangkabau (Jakarta: Pustaka Panjimas).

[30]Edison dan Nasrun Dt Marajo Sungut 2010 Tambo mlnangkabau: budaya dan hukum adat di minangkaba, (Bukittinggi: Kristal Multmudia).

[31] Radjab M 1969 Sistem kekerabatan di minangkabau (Padang: Centre for Minangkabau Studies Press)

[32] Bourdieu P 2018 The forms of capital in the sociology of economic life Third edition.

[33] Radjab M 1969 Sistem kekerabatan di minangkabau, (Padang: Centre for Minangkabau Studies Press)

[34] Muliono dan Welhendri Azwar 2013 Pengemis dan disfungsi sistem sosial kultural dalam masyarakat minangkabau, (Padang: Imam Bonjol Press).

[35] Pranadji Tri 2006 Penguatan modal sosial untuk pemberdayaan masyarakat pedesaan dalam pengelolaan agroekosistem lahan kering, jurnal agro ekonomi, V 242.

[36] Azwar Welhendri et al 2018 Nagari minangkabau: the study of indigenous institutions in west sumatra, indonesia. Jurnal Bina Praja, Vol.10.

[37] Ife Jim dan Frank Tesoriero 2016 Community development (Yogyakarta: Pustaka Pelajar). 